\title{
Relationship between Important Deciduous Traits in Bulgaria
}

\author{
Simona Peteva ${ }^{1, *}$, Hristina Kalcheva ${ }^{2}$, Mariyana Lyubenova ${ }^{1}$ \\ ${ }^{1}$ Department of Ecology and Environmental Protection, Faculty of Biology, Sofia University "St. Kliment Ohridski", Bulgaria \\ ${ }^{2}$ Institute of Biodiversity and Ecosystem Research, Sofia, Bulgaria
}

Copyright $@ 2017$ by authors, all rights reserved. Authors agree that this article remains permanently open access under the terms of the Creative Commons Attribution License 4.0 International License

\begin{abstract}
Forest ecosystems cover about 30\% of the Earth's surface and provide important ecosystem goods and services. Forest traits: specific leaf area (SLA), leaf weight ratio (LWR) and growth index (It) are among the key indicators of forest ecosystems functioning. The investigation deals with meta-analysis (including ANOVA and RDA analysis) for 20 Bulgarian locations of Quercus cerris $\mathrm{L}$. and $Q$. frainetto Ten. forests. The results are verified with the data from TRY database. For all analysis as a response, variables are chosen selected indexes - SLA, LWR and It and as explanatory variables - listed characteristics of locations: latitude, longitude, altitude, precipitation and temperature. The positive correlation of growth index and SLA and negative - with altitude for all locations are obtained. The growth index correlated negatively with LWR and positively with longitude only for Bulgarian locations. The established dependences are indispensable for higher precision of the ongoing analyzes, filling the gaps of data and creating a new generation of vegetation models.
\end{abstract}

Keywords Growth Index, Specific Leaf Area, Leaf Weight Ratio, Meta-analysis, Turkey Oak, Hungarian Oak, Bulgaria

\section{Introduction}

Forest ecosystems, cover about 30\% of the Earth's surface and provide important goods and services from ecosystems, including food, feed, water, shelter, nutrients, and also have both cultural and recreational value. Forests provide habitat for a wide range of species and help to alleviate land degradation and desertification. This significant role is decisive for the adaptation planning to climate change by maintaining ecosystem services and providing livelihoods. Deforestation and degradation of forests in developing countries account for around one-sixth of the world's $\mathrm{CO}_{2}$ emissions, European Commission [10].

Bulgaria is among the countries with the largest number of forests in Europe. They cover one third of the country's territory and most of them are of natural origin, Lalova [23]. Only about $4 \%$ of them have been preserved as "pristine forests", which are not affected by human activity. The forests of Bulgaria have a key role to play in preventing erosion and preserving the sources of 3.4 billion cubic meters. Water used for water supply in agriculture and fisheries, for production and energy purposes, Lyubenova [25]. Forests are a refuge for the populations of 43 globally endangered species of animals and plants. Bulgarian forests are a place for recreation and tourism and provide economic and social benefits for the people, Lyubenova [26]. There are many problems and threats to the Bulgarian forests. The most serious are the short-sighted management of forest resources and the high level of illegal activities in the forest sector, WWF [47].

The Bulgarian forests are characterized by extremely rich biodiversity of coniferous and deciduous trees. The distribution of forest areas by type of forest follows a characteristic trend associated with a permanent decrease in the area of coniferous forests and coniferous crops, which as a result of the large-scale afforestation programs was increased sharply in the middle of the last century, Bondev et al. [10], Georgieva \& Lyubenova [12]. After 1990 this area is gradually decreasing and at present coniferous forests account for $21.6 \%$ of the country's forests (1 145781 ha). Deciduous forests occupy 68.4\% of the total area of forest areas in the country and continue to expand their share.

The forests of Bulgaria are perceived by Bulgarian society as part of their national wealth and national identity. These economic, social and environmental functions are important for the sustainable development of society and the improvement of living conditions, especially in rural and mountainous areas, Bondev [2]. To a large extent, 
these functions are indispensable not only in the national but also in the global sense. Forestry is the practical application of scientific, economic and social principles used in the creation and management of forests. Deforestation and desertification adversely affect agricultural productivity, human health as well as livestock as well as economic activities such as ecotourism.

The plant are the morphological, anatomical, physiological, biochemical and phenological features of plants and their organisms - determine how primary producers react to environmental factors; how they affect ecosystem processes and services, linking species richness to ecosystem functional diversity. Their data is the basis for a wide range of studies ranging from evolutionary biology, population and functional ecology to biogeography Kattge et al. [20]. Forest features and trees, in turn, are essential to Earth's life, fulfilling an incredible role, namely maintaining life through their ability to combine sunlight, water, nutrients and carbon dioxide to produce woody biomass and release the oxygen that holds the balance of our planet.

Forest traits and trees, in turn, are essential to Earth's life, fulfilling an incredible role, namely maintaining life through their ability to combine sunlight, water, nutrients and carbon dioxide to produce woody biomass and release the oxygen that holds the balance of our planet. Treat ecology has a long history but was rediscovered only in 1995 for three main reasons:

- $\quad$ Understanding the functions of communities;

- Defining mechanisms for their functioning;

- Use of traits as strategic axes for the sustainable development of forest ecosystems.

In 2007, the TRY initiative (TRY - not an acronym, but an expression of general opinion: http://www.try-db.org) began collecting data on the plant characteristics (traits) of the various aspects of plant functioning on a global scale to make the data available in a compatible format via a single portal. Based on the broad approval of the Plant Trait Community (PTC), the TRY initiative has achieved unprecedented "coverage" of plant characteristics called traits and is now working to create a global global data repository, Kattge et al. [20]. First Poorter and Remkes, [38] explore the relationship between leaf weight ratio (LWR), specific leaf area (SLA), leaf area ratio (LAR) and relative growth rates (RGR). They come to the conclusion that both LWR and SLAs correlate positively with the other two indices, namely LAR and RGR. However, the positive relationship between LWR and RGR appears to be less positive $(\mathrm{P}<0.01)$ than that of the other indices. In turn, the SLA index appears to have the strongest positive correlation with the RGR index. The team of Pickup et al. (2005) makes a comparison between the indexes - SLA and wood density (WD). They come to the conclusion that species with a leaf size of $1000 \mathrm{~mm}^{2}$, all of highland and rainforest habitats, have an index density or wood density of WD below $0,7 \mathrm{~g} \mathrm{~cm}^{-3}$, which can reach even lower values $-0,4$ g.cm ${ }^{-3}$. In addition, there is a strong negative relationship between the WD index and the size of the leaves for the same habitats. The WD index is a key variable for assessing the wood mass. The index differs for different types of wood biomass - wood, bark, clone roots, etc., also for different species but for the same species under different environmental conditions, Henry et al. [15]. As early as 2001, Ketterings et al., [19] suggest that WD strongly depends on the habitat, climate and management of the forestry concerned.

Another publication by Poorter et al., [38] proves that the RGR index correlates negatively with the SLA and WD indices when all habitats are analyzed through a collaborative approach. On the other hand, Yablon, [50] finds that for all species it has combined, the maximum diameter of breast height (DBH) is highly dependent on soil composition, unlike WD, which correlates poorly. In addition, links between the soil profile and the habitat zone indicate that plant functional types (PFTs) are formed under different conditions and ways. Again, Yablon [50] found that the size of the trees strongly correlated with the soil composition, and on the soil mass the soil had little influence. In the case of low stem species, a maximum correlation of DBH with soil composition and minimum with SLA is observed. The study of individual functional groups results in a mismatch in the results obtained in their combined study. This proves that species react differently to environmental factors (gradients). It is a completely natural process conditioned by their physiological and evolutionary nature. In turn, the Yablon [50] analyzes prove the immense role of the habitat in the formation of the relevant tree species.

Till now, there is no information on the dependencies between the four indexes: SLA, WD, LWR, RGRs and between the characteristics of their respective locations latitude, longitude, altitude, temperature and precipitations. This changed in April 2016 when the reunification of European scientists, including Bulgarians, gave a new light on the subject. Based on meta-analysis Lyubenova et al., [32] analyze 74 habitats from 14 countries in Europe, North America and Asia for a total of 9 species of deciduous and coniferous trees (data obtained from the TRY world database). In their study, the relevant functional relationships between forest trees (SLA, LWR, WD), the growth index of the Dendrochronology (It) and the geographical characteristics of the habitat: latitude (Lat.), longitude (Long.), altitude (Alt.), temperature (T) and precipitation (Prec) mostly concentrate on the existing links between the indexes using the innovative meta-analysis platform to fill data gaps by statistically restoring them.

The purpose of this research is to collect and analyze data on forest characteristics (It, SLA and LWR) for the species: Quercus cerris L and Q. frainetto Ten., comparing them with the It index data from the dendrochronology in search of functional relationships between them. In order to achieve the stated goal, the following main tasks were set 
for implementation:

1. Collection of dendrochronological data for forest habitats from Bulgarian and other geographical locations;

2. Data collection and calculation of the surveyed key indices for Bulgarian forest habitats;

3. Understanding and learning the SPPAM program features, version 2;

4. Learn and use the functions of Canoco, version 4.5 and Statistica, version 7.0;

5. Exploration and application of the meta-analysis in search of the functional relationships between the indexes (It, SLA, and LWR) for the species and the factors of the environment (Lat., Long., Alt., T, P).

6. Search for functional links between the indexes - It, SLA, LWR and the locality characteristics (Lat., Long., Alt., T, P) for the respective species and habitat;

7. Seek functional links between the SLA and LWR indices for the species and habitat concerned;

8. Search for functional links between the SLA, LWR, and Growth Index, It, for the relevant species and habitat.

9. Comparison of the results obtained with the same indexes (with WD added) from the TRY database Kattge et al. [20]. Establishing functional dependencies will allow the recovery of missing data and the creation of longer ranges of data based on the growth index series as a benchmark. This can be used in the development of the new generation of global dynamic patterns of plant cover.

\section{Materials and Methods}

For the selection of test areas from which the wood samples were taken, a forest management project provided by the Sevlievo State Enterprise was studied.

The process of exporting data has occurred in the following steps:

- Breakdown of data rows;

- Keeping the selected rows in a relational database;

- $\quad$ Save data integrity and transfer it to tabular format;

- Comparing and searching for match of data from TRY base and SP-PAM base - this process is performed by the name of the corresponding tree species;

- Selection of data for the four indexes - SLA, LWR, WD (for TRY types only) and It.

- Select locality data for all analyzes as follows: Lat., Long., Alt., $\mathrm{T}$ and $\mathrm{P}$.

- The final step is to export growth data index It from the SP-PAM base.

Data on the $S L A$ and $L W R$ indices, including geographic coordinates, climatic data and sampling years for two species: Quercus cerris L. and Quercus frainetto Ten., were collected from numerous Bulgarian scientific publications in the period: 1994-1999 like Lalova, [23]; Lyubenova, [24, 25, 26]; Lyubenova et al., [28, 31]; Bondev et al., [4]; Georgieva et al. [12, 13]; Ljubenova et al., [27] from various localities - Table 1 . The own samples were conducted in two locations and are colored in yellow - Table 1. They are respectively - National park "Vitosha" - section 1096, subsection "y"; protected area of NATURA 2000 "Al. Stamboliiski ", section 315, subsection "k" figure 1 (a), (b) and figure 1 (c), (d). 
Table 1. Characteristics of locations

\begin{tabular}{|c|c|c|c|c|c|c|c|c|}
\hline Ref.** & Locations & $\begin{array}{l}\text { Latitude } \\
\text { (Lat.) }\end{array}$ & $\begin{array}{c}\begin{array}{l}\text { Longitude } \\
\text { (Long.) }\end{array} \\
\end{array}$ & $\begin{array}{l}\text { Altitude } \\
\text { (Alt.), m }\end{array}$ & $\begin{array}{l}\begin{array}{l}\text { Precipitation } \\
\text { av } \\
\text { (Prec. av), mm }\end{array} \\
\end{array}$ & $\begin{array}{l}\mathrm{T} \text { av, } \\
{ }^{\circ} \mathrm{C}\end{array}$ & FAO soil type & Year * \\
\hline \multicolumn{9}{|c|}{ Quercus cerris L. } \\
\hline 27 & $\begin{array}{l}\text { Zlogosh village, } \\
\text { Zemen mountain }\end{array}$ & 42.46 & 22.64 & 1040 & 659.50 & 8.81 & $\begin{array}{l}\text { Chromic } \\
\text { luvisols }\end{array}$ & 1991 \\
\hline 24 & $\begin{array}{c}\text { Balova shuma } \\
\text { village, Montana } \\
\text { city } \\
\end{array}$ & 43.41 & 23.23 & 147 & 364.60 & 11.32 & Luvisols & 1992 \\
\hline 23 & Bozurica village & 43.52 & 24.60 & 200 & 496.20 & 10.03 & Chernozem & 1992 \\
\hline 26 & Sevlievo city & 43.03 & 25.10 & 300 & 378.30 & 11.34 & Gray luvisols & 1992 \\
\hline 27 & $\begin{array}{l}\text { Zlogosh village, } \\
\text { Zemen mountain }\end{array}$ & 42.46 & 22.64 & 1040 & 495.80 & 9.59 & $\begin{array}{l}\text { Chromic } \\
\text { luvisols }\end{array}$ & 1992 \\
\hline 26 & Sevlievo city & 43.03 & 25.10 & 300 & 469.50 & 11.11 & Gray luvisols & 1993 \\
\hline 25 & $\begin{array}{l}\text { Zlogosh village, } \\
\text { Zemen mountain }\end{array}$ & 42.46 & 22.64 & 1040 & 465.00 & 9.48 & Cambisols & 1993 \\
\hline 27 & $\begin{array}{l}\text { Zlogosh village, } \\
\text { Zemen mountain }\end{array}$ & 42.46 & 22.64 & 1040 & 465.00 & 9.48 & $\begin{array}{l}\text { Chromic } \\
\text { luvisols }\end{array}$ & 1993 \\
\hline 24 & $\begin{array}{l}\text { Domlyan village, } \\
\text { Sarnena forest }\end{array}$ & 42.53 & 24.92 & 500 & 516.40 & 12.30 & Cambisols & 1994 \\
\hline 21 & $\begin{array}{l}\text { Zlogosh village, } \\
\text { Zemen mountain }\end{array}$ & 42.46 & 22.64 & 1040 & 527.40 & 10.57 & Cambisols & 1994 \\
\hline 28 & $\begin{array}{l}\text { Domlyan village, } \\
\text { Sarnena forest }\end{array}$ & 42.53 & 24.92 & 500 & 628.60 & 11.09 & Cambisols & 1995 \\
\hline $12,13,31$ & Govezda village & 43.38 & 23.08 & 284 & 482.50 & 11.88 & Luvisols & 2003 \\
\hline $12,13,31$ & $\begin{array}{l}\text { Suhodol quarter, } \\
\text { Lyulin mountain }\end{array}$ & 42.70 & 23.23 & 659 & 525.80 & 10.88 & Leptosols & 2003 \\
\hline $12,13,31$ & $\begin{array}{c}\text { Kokalyan } \\
\text { monastery, Plana } \\
\text { mountain }\end{array}$ & 42.60 & 23.45 & 966 & 525.80 & 10.88 & Leptosols & 2003 \\
\hline $12,13,31$ & $\begin{array}{l}\text { Gorni Lozen village, } \\
\text { Lozen mountain }\end{array}$ & 42.60 & 23.48 & 700 & 525.80 & 10.88 & Leptosols & 2003 \\
\hline $12,13,31$ & $\begin{array}{l}\text { Drenovo village, } \\
\text { Mala mountain }\end{array}$ & 42.95 & 23.16 & 895 & 525.80 & 10.88 & Cambisols & 2003 \\
\hline $12,13,31$ & $\begin{array}{c}\text { Kremikov } \\
\text { monastery, Sofia } \\
\text { mountain } \\
\end{array}$ & 42.80 & 23.51 & 687 & 525.80 & 10.88 & Cambisols & 2003 \\
\hline $12,13,31$ & $\begin{array}{l}\text { Cheparlinzi village, } \\
\text { West Old mountain }\end{array}$ & 43. 02 & 22.91 & 619 & 482.50 & 11.88 & Cambisols & 2003 \\
\hline $12,13,31$ & Chuprene village & 43.56 & 22.77 & 307 & 488.00 & 11.66 & Luvisols & 2003 \\
\hline $12,13,31$ & Govezda village & 43.39 & 23.07 & 223 & 537.10 & 11.99 & Rendzic & 2004 \\
\hline $12,13,31$ & $\begin{array}{l}\text { Suhodol quarter, } \\
\text { Lyulin mountain }\end{array}$ & 42.70 & 23.23 & 659 & 549.70 & 11.04 & Leptosols & 2004 \\
\hline $12,13,31$ & $\begin{array}{c}\text { Kokalyan } \\
\text { monastery, Plana } \\
\text { mountain }\end{array}$ & 42.60 & 23.45 & 966 & 549.70 & 11.04 & Leptosols & 2004 \\
\hline $12,13,31$ & $\begin{array}{l}\text { Gorni Lozen village, } \\
\text { Lozen mountain }\end{array}$ & 42.60 & 23.48 & 700 & 549.70 & 11.04 & Leptosols & 2004 \\
\hline $12,13,31$ & $\begin{array}{c}\text { Drenovo village, } \\
\text { Mala mountain }\end{array}$ & 42.95 & 23.16 & 895 & 549.70 & 11.04 & Cambisols & 2004 \\
\hline $12,13,31$ & $\begin{array}{c}\text { Kremikov } \\
\text { monastery, Sofia } \\
\text { mountain }\end{array}$ & 42.80 & 23.51 & 687 & 549.70 & 11.04 & Cambisols & 2004 \\
\hline $12,13,31$ & $\begin{array}{l}\text { Cheparlinzi village, } \\
\text { West Old mountain }\end{array}$ & 43. 02 & 22.91 & 619 & 537.10 & 11.99 & Cambisols & 2004 \\
\hline $12,13,31$ & Chuprene village & 43.56 & 22.76 & 360 & 577.70 & 11.77 & Luvisols & 2004 \\
\hline$* * *$ & $\begin{array}{l}\text { Protected area } \\
\text { "Alexander } \\
\text { Stambolijski” }\end{array}$ & 43.07 & 25.07 & 354 & 634.00 & 13.80 & Luvisols & 2016 \\
\hline$* * * *$ & $\begin{array}{l}\text { Natural park } \\
\text { „Vitosha” }\end{array}$ & 42.64 & 23.22 & 1126 & 532.00 & 10.68 & Cambisols & 2016 \\
\hline \multicolumn{9}{|c|}{ Quercus frainetto Ten. } \\
\hline 27 & $\begin{array}{l}\text { Zlogosh village, } \\
\text { Zemen mountain }\end{array}$ & 42.46 & 22.64 & 1040 & 659.50 & 8.81 & $\begin{array}{l}\text { Chromic } \\
\text { luvisols }\end{array}$ & 1991 \\
\hline 24 & Balova shuma & 43.41 & 23.23 & 147 & 360.50 & 11.79 & Luvisols & 1992 \\
\hline
\end{tabular}




\begin{tabular}{|c|c|c|c|c|c|c|c|c|}
\hline & $\begin{array}{l}\text { village, Montana } \\
\text { city }\end{array}$ & & & & & & & \\
\hline 23 & Bozurica village & 43.52 & 24.60 & 200 & 364.60 & 11.32 & Chernozem & 1992 \\
\hline 26 & Sevlievo city & 43.03 & 25.10 & 300 & 378.30 & 11.34 & Gray luvisols & 1992 \\
\hline 27 & $\begin{array}{l}\text { Zlogosh village, } \\
\text { Zemen mountain }\end{array}$ & 42.46 & 22.64 & 1040 & 495.80 & 9.59 & $\begin{array}{l}\text { Chromic } \\
\text { Luvisols }\end{array}$ & 1992 \\
\hline 26 & Sevlievo city & 43.03 & 25.10 & 300 & 469.50 & 11.11 & Gray luvisols & 1993 \\
\hline 27 & $\begin{array}{l}\text { Zlogosh village, } \\
\text { Zemen mountain }\end{array}$ & 42.46 & 22.64 & 1040 & 465.00 & 9.48 & $\begin{array}{l}\text { Chromic } \\
\text { Luvisols }\end{array}$ & 1993 \\
\hline 25 & $\begin{array}{l}\text { Zlogosh village, } \\
\text { Zemen mountain }\end{array}$ & 42.46 & 22.64 & 1040 & 465.00 & 9.48 & Cambisols & 1993 \\
\hline 29 & $\begin{array}{l}\text { Varbovo village, } \\
\text { East Rhodopes }\end{array}$ & 41.77 & 25.87 & 300 & 517.6 & 13.27 & $\begin{array}{l}\text { Chromic } \\
\text { Luvisols } \\
\end{array}$ & 1994 \\
\hline 28 & $\begin{array}{l}\text { Domlyan village, } \\
\text { Sarnena forest }\end{array}$ & 42.53 & 24.92 & 500 & 516.40 & 12.30 & Cambisols & 1994 \\
\hline 25 & $\begin{array}{l}\text { Zlogosh village, } \\
\text { Zemen mountain }\end{array}$ & 42.46 & 22.64 & 1040 & 527.40 & 10.57 & Cambisols & 1994 \\
\hline 28 & $\begin{array}{l}\text { Staro Oryahovo } \\
\text { village, Old } \\
\text { mountain }\end{array}$ & 42.98 & 27.80 & 150 & 478.30 & 12.98 & Pseudopodzolic & 1994 \\
\hline 28 & $\begin{array}{l}\text { Domlyan village, } \\
\text { Sarnena forest }\end{array}$ & 42.53 & 24.92 & 500 & 628.60 & 11.09 & Cambisols & 1995 \\
\hline 4 & $\begin{array}{c}\text { Prisad village, } \\
\text { Strandzha mountain }\end{array}$ & 42.38 & 27.38 & 50 & 597.20 & 11.97 & Planosols & 1996 \\
\hline $12,13,31$ & Govezda village & 43.38 & 23.08 & 284 & 482.50 & 11.88 & Luvisols & 2003 \\
\hline $12,13,31$ & $\begin{array}{l}\text { Suhodol quarter, } \\
\text { Lyulin mountain }\end{array}$ & 42.70 & 23.23 & 659 & 525.80 & 10.88 & Leptosols & 2003 \\
\hline $12,13,31$ & $\begin{array}{c}\text { Kokalyan } \\
\text { monastery, Plana } \\
\text { mountain }\end{array}$ & 42.60 & 23.45 & 966 & 525.80 & 10.88 & Leptosols & 2003 \\
\hline $12,13,31$ & $\begin{array}{l}\text { Gorni Lozen village, } \\
\text { Lozen mountain }\end{array}$ & 42.60 & 23.48 & 700 & 525.80 & 10.88 & Leptosols & 2003 \\
\hline $12,13,31$ & $\begin{array}{l}\text { Drenovo village, } \\
\text { Mala mountain }\end{array}$ & 42.95 & 23.16 & 895 & 525.80 & 10.88 & Cambisols & 2003 \\
\hline $12,13,31$ & $\begin{array}{c}\text { Kremikov } \\
\text { monastery, Sofia } \\
\text { mountain }\end{array}$ & 42.80 & 23.51 & 687 & 525.80 & 10.88 & Cambisols & 2003 \\
\hline $12,13,31$ & $\begin{array}{l}\text { Cheparlinzi village, } \\
\text { West Old mountain }\end{array}$ & 43. 02 & 22.91 & 619 & 482.50 & 11.88 & Cambisols & 2003 \\
\hline $12,13,31$ & Chuprene village & 43.56 & 22.77 & 307 & 488.00 & 11.66 & Luvisols & 2003 \\
\hline $12,13,31$ & Govezda village & 43.39 & 23.07 & 223 & 537.10 & 11.99 & Rendzic & 2004 \\
\hline $12,13,31$ & $\begin{array}{l}\text { Suhodol quarter, } \\
\text { Lyulin mountain }\end{array}$ & 42.70 & 23.23 & 659 & 549.70 & 11.04 & Leptosols & 2004 \\
\hline $12,13,31$ & $\begin{array}{c}\text { Kokalyan } \\
\text { monastery, Plana } \\
\text { mountain }\end{array}$ & 42.60 & 23.45 & 966 & 549.70 & 11.04 & Leptosols & 2004 \\
\hline $12,13,31$ & $\begin{array}{l}\text { Gorni Lozen village, } \\
\text { Lozen mountain }\end{array}$ & 42.60 & 23.48 & 700 & 549.70 & 11.04 & Leptosols & 2004 \\
\hline $12,13,31$ & $\begin{array}{l}\text { Drenovo village, } \\
\text { Mala mountain }\end{array}$ & 42.95 & 23.16 & 895 & 549.70 & 11.04 & Cambisols & 2004 \\
\hline $12,13,31$ & $\begin{array}{c}\text { Kremikov } \\
\text { monastery, Sofia } \\
\text { mountain }\end{array}$ & 42.80 & 23.51 & 687 & 549.70 & 11.04 & Cambisols & 2004 \\
\hline $12,13,31$ & $\begin{array}{l}\text { Cheparlinzi village, } \\
\text { West Old mountain }\end{array}$ & 43. 02 & 22.91 & 619 & 537.10 & 11.99 & Cambisols & 2004 \\
\hline $12,13,31$ & Chuprene village & 43.56 & 22.76 & 360 & 577.70 & 11.77 & Luvisols & 2004 \\
\hline$* * *$ & $\begin{array}{l}\text { Protected area } \\
\text { "Alexander } \\
\text { Stambolijski" }\end{array}$ & 43.07 & 25.07 & 355 & 634.00 & 13.80 & Luvisols & 2016 \\
\hline$* * * *$ & $\begin{array}{l}\text { Natural park } \\
\text { "Vitosha" }\end{array}$ & 42.64 & 23.22 & 1126 & 532.00 & 10.68 & Cambisols & 2016 \\
\hline
\end{tabular}

* Under the year understands the year of sampling

** Source refers to the relevant scientific publication in the references

*** Own sample from European network "Natura 2000"

**** Own sample from Natural Park "Vitosha” according to the bulgarian law from 1998 


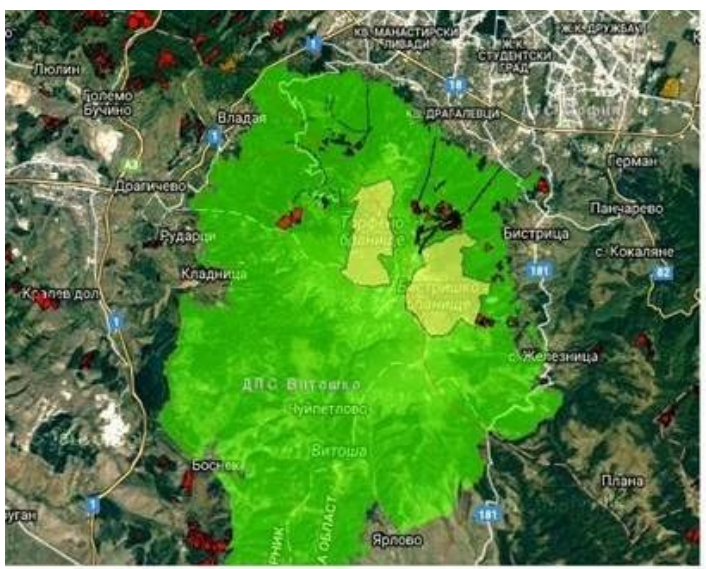

a

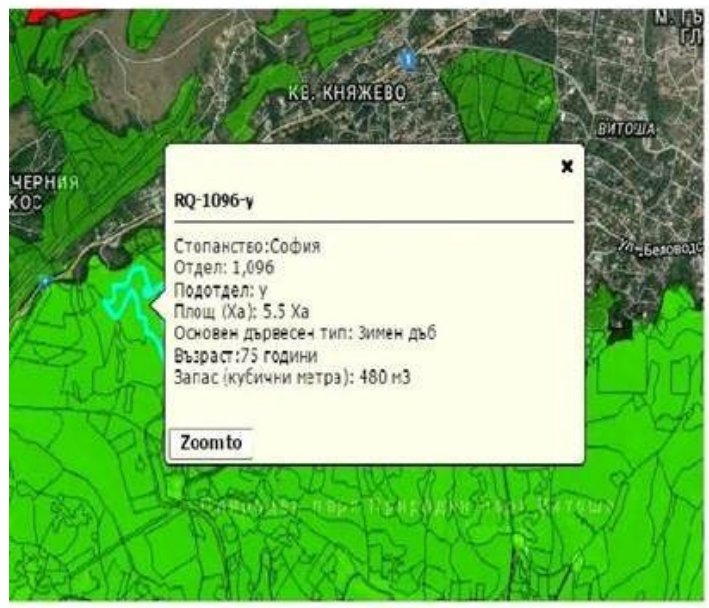

b

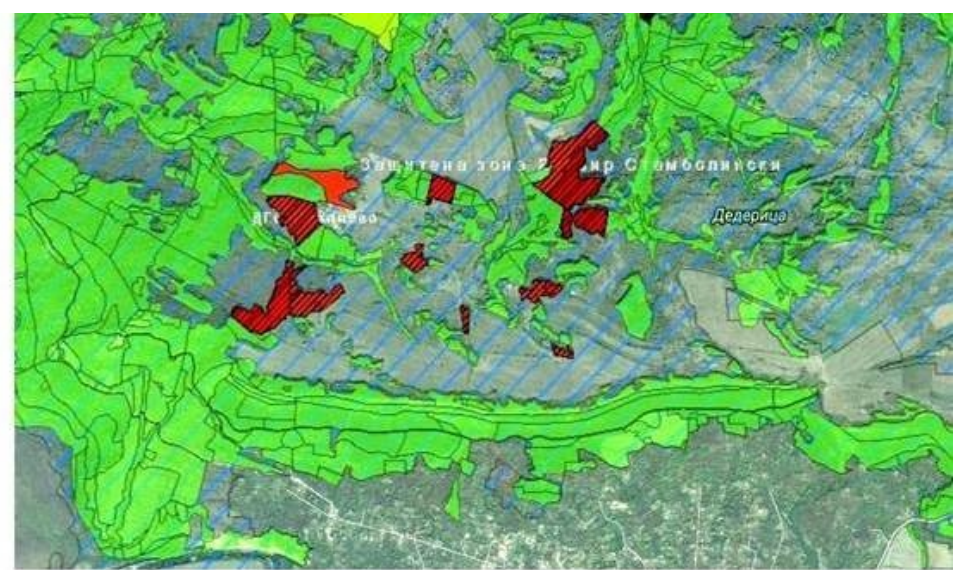

C

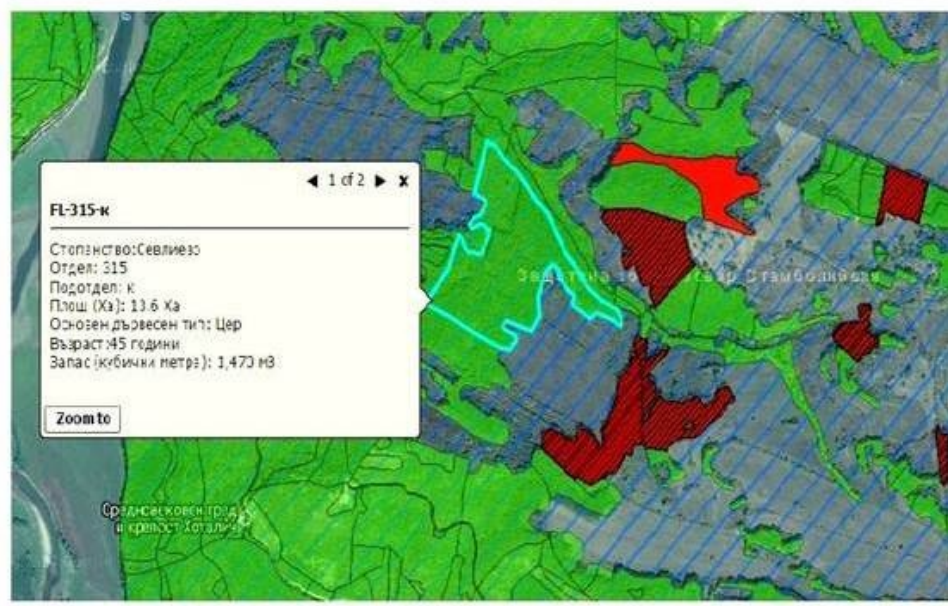

d

Figure 1. (a) National park "Vitosha"; (b) section 1096, subsection "y"; (c) Protected area of NATURA 2000 "Al. Stamboliiski "; (d) section 315, subsection "k"

Data for locations in Europe, USA, Canada and Kyrgyzstan for comparative analysis, meta-analysis and verification were provided thanks to the global TRY database. This data is for specific leaf area (SLA), leaf weight ratio $(L W R)$ and wood density (WD), including geographic coordinates, climatic data, and sampling years (1965-2002). The information on the characteristics of the Bulgarian localities (habitats) and the SLA and $L W R$ indexes are the result of a study of numerous Bulgarian scientific publications, creation of a database based on them and calculations. The data for two Bulgarian locations are the result of own research. The data for comparing and verifying the results of the Bulgarian localities are obtained from the TRY database (https://www.try-db.org/TryWeb/Home.php). The It data (all categories) are taken from the International Tree Ring (ITR) and SP-PAM databases (http://www.ncdc.noaa.gov/data-access/paleoclimatologydata/datasets/tree-ring).

The weighing method Nichiporovich [35] is used to measure specific leaf area (SLA) in Bulgarian locales. It consists of the following: first are collected randomly leaves of different parts of the crown. The minimum must be three samples every with 50 leaves, which are weighted $\left(\mathrm{T}_{1}\right)$. Then the leaves have been four times punctured by a punch with a certain area of the aperture so as to obtain 200 small circles that are also weighed $\left(\mathrm{T}_{\mathrm{c}}\right)$. The leaf surface $(\mathrm{s})$ of the sample is calculated by the simple triple rule:

$$
\mathrm{S}=\mathrm{T}_{\mathrm{c}} * 200 * \mathrm{~s}_{\mathrm{p}} / \mathrm{T}_{\mathrm{c}},
$$

where $s_{p}$ is the surface of the punch (calculated by the circle formula: $\pi . r^{2}$ )

For the total weight of leaf biomass using the simple triple rule, the total leaf surface $S_{\mathrm{L}}$ is calculated:

$$
\mathrm{S}_{\mathrm{L}}=(\mathrm{T} . \mathrm{s}) / \mathrm{t} \text {, }
$$

where: $\mathrm{T}$ is the weight of leaf biomass; $\mathrm{T}$ - the weight of the sample; $\mathrm{S}$ - the leaf surface of the sample

$\mathrm{S}_{\mathrm{L}}$ is equal to SLA.

The leaf weight ratio (LWR) is the ratio of the plant leaf 
mass to the total mass with the unit of measurement $\mathrm{g}^{-\mathrm{g}^{-1}}$ (a biomass distribution measure in the leaves). LWR is actually a dimensionless coefficient. The SLA reciprocal index, known in the western literature as specific leaf weight (SLW), is often confused about the LWR coefficient. By definition, each "specific" index has to be related to mass, so the SLW index will always be equal to 1 , Jarvis [17]. For this reason, the following formula is used for LWR:

$$
\mathrm{LWR}=\mathrm{W}_{\mathrm{L}} / \mathrm{W},
$$

Where $\mathrm{W}_{\mathrm{L}}$ is the leaf weight and $\mathrm{W}$ is the total phytomas.

The It index of the dendrochronology is calculated using the equation:

$$
\text { It }=\text { Rt / Gt, }
$$

where: It is the radial growth index in a given year; the Rt is measured radial growth rate for a given year and the Gt is the value for the radial growth rate of a given year determined by the regression equation, Mirchev et al. [33]. It is also a dimensionless dimension. Dendrochronological sequences are measured and processed using TsapWin (http://www.rinntech.de/index-52147.html), COFECHA, Grissino - Mayer [14] and SPPAM (www.e-ecology.org).

For the statistics is used RDA or redundancy analysis, Ramette [39] with the program Canoco 4.5 for Windows, ter Braak, Smilauer [41] and one-way ANOVA analysis. In the multidimensional RDA analysis, much of the data is based on specific program logarithm and standardized where necessary to normalize and to remove the influence of differences in the analysis. Variable characteristics, which are the indices by species: specific leaf area, leaf weight ratio, growth index (SLA, LWR and It), are included in the RDA as variable response variables and the environmental factors: latitude, longitude, altitude, temperature, precipitation (Lat.; Long; Alt; T; Prec.) participate in analyzes as independent explanatory variables.

Dispersion analysis or ANOVA is a method used in statistics to test hypotheses for equality between more than two averages. Through this hypothesis test, the extent to which the impact of a cause factor or a group of cause factors is statistically significant or not.

Thus, dispersion analysis refers to methods of link and dependency testing. This method is best suited for use when the significance of the factor-factor is represented on the weak scale (usually the nominal) and the significance of the resultant attribute is on the strong scale, i. Have a numerical expression, Yordanova [51].

Through the dispersion analysis, it can only be ascertained whether there is a dependency between the phenomena studied, but the severity or the strength of the dependency and its direction cannot be measured.
Dispersion analysis or ANOVA is a method used in statistics to verify hypotheses for equality between more than two averages. This hypothesis check can assess whether the impact of a cause factor or a group of cause factors is statistically significant or not, Yordanova [51].

Thus, dispersion analysis refers to the methods of relationship and dependency testing. This method is best suited for use when the significance of the factor-factor is represented on the weak scale (usually the nominal) and the significance of the resultant sign - on the strong scale, ie. have a numerical expression Yordanova [51].

Through the dispersion analysis, it can only be ascertained whether there is dependence between the phenomena (signs) that are being investigated, but the extent or severity of the dependency and its direction can not be measured. Application: To apply the dispersion analysis, the following conditions must be met:

1. An analysis needs to be made to determine which signs are interrelated, which factors are and what the results are.

2. The distribution of the units in the aggregate by the resultant sample from which the samples are to be sampled shall be normal or close to normal.

3. The samples emanating from the population must have equal (uniform) dispersions.

4. The data used in the dispersion analysis are emitted from independent random samples.

5. When examining the influence of a factor, it is possible to control side-by-side factors.

In this work, ANOVA is used to test the differences in the values of the surveyed indices among species, genera or distribution (countries, continents).

\section{Results}

\section{Results from RDA Analysis}

For Quercus cerris L., the five factors of the environment (Lat., Long., Alt., T, Prec.) explain reliably $42 \%$ of the changes in the three indexes (It, SLA, LWR). The statistical results are: $\mathrm{AllEV}=1.000$, CanEV $=0.427$, F-ratio $=3.438$, p-value $=0.0280)$. According to the RDA analysis - Figure 2:

- It index correlates neutral with SLA, strongly positive with Long., moderately positive with Lat. and T, but strongly negative with Alt., moderately negative with $L W R$, and negative with Prec.

- The SLA index correlates poorly with Long, Alt, neutral with $I t$, and moderately negative with $L W R$ and Lat.; Strongly negative with $T$ and Prec.

- $\quad$ The $L W R$ index correlates negatively with SLA and It, strongly negative with Long, and strongly positive with Prec., moderately positive with Alt. and slightly positive with $T$. 


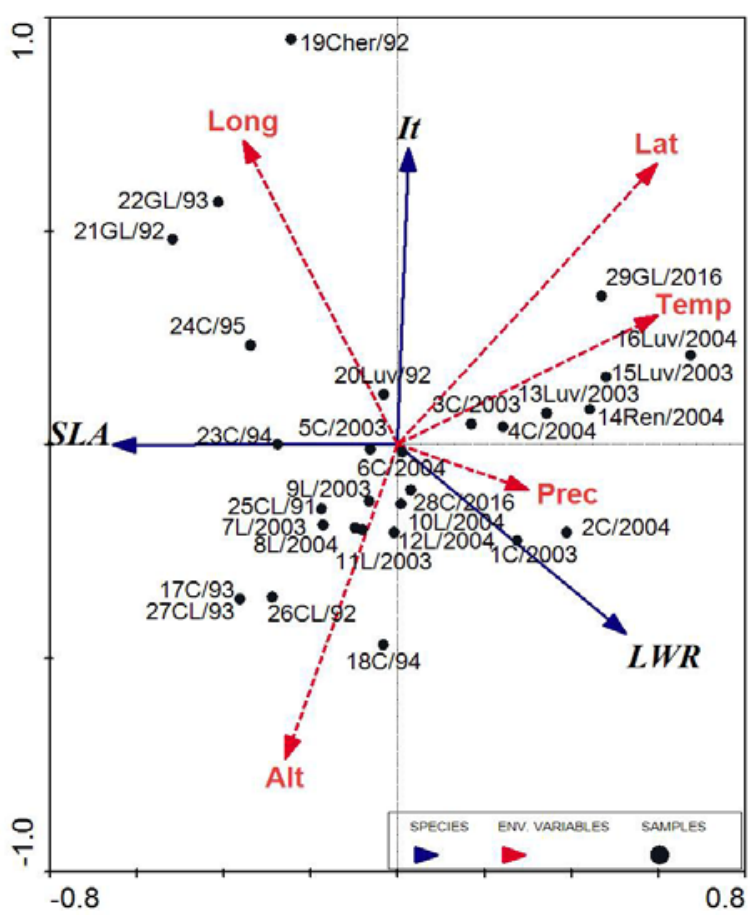

Figure 2. The RDA triples of the correlations of the three indices (species: SLA, It, and LWR) with the five environmental factors (environmental variables: Lat.; Long; Alt.; T; Prec.) and sampling locations. Statistical results: AllEV $=1.000$, Can $\mathrm{EV}=0.427$, F-ratio = 3.438, p-value $=0.0280$

For Quercus frainetto Ten., the five factors of the environment (Lat.; Long; Alt; T; Prec.) account for $51 \%$ of the changes in the three indexes (It, SLA, LWR). The statistical results are: AllEV $=1.000$, CanEV $=0.513$, F-ratio $=5.474$, p-value $=0.0020$.

According to the RDA analysis - figure 3 :

It indexes poorly positive with $S L A$, moderately positive with $T$ and Prec, very positive with Long, moderately negative with Lat., and strongly negative with Alt. and $L W R$.

The SLA index correlates moderately negatively with Lat., slightly negative with Alt., $L W R$, and weakly positive with It and Long, and almost neutral with $T$ and Prec.

The $L W R$ index correlates strongly negatively with Long and $I t$, almost neutral with $T$ and Prec., and very lively with Alt. and slightly positive with Lat.

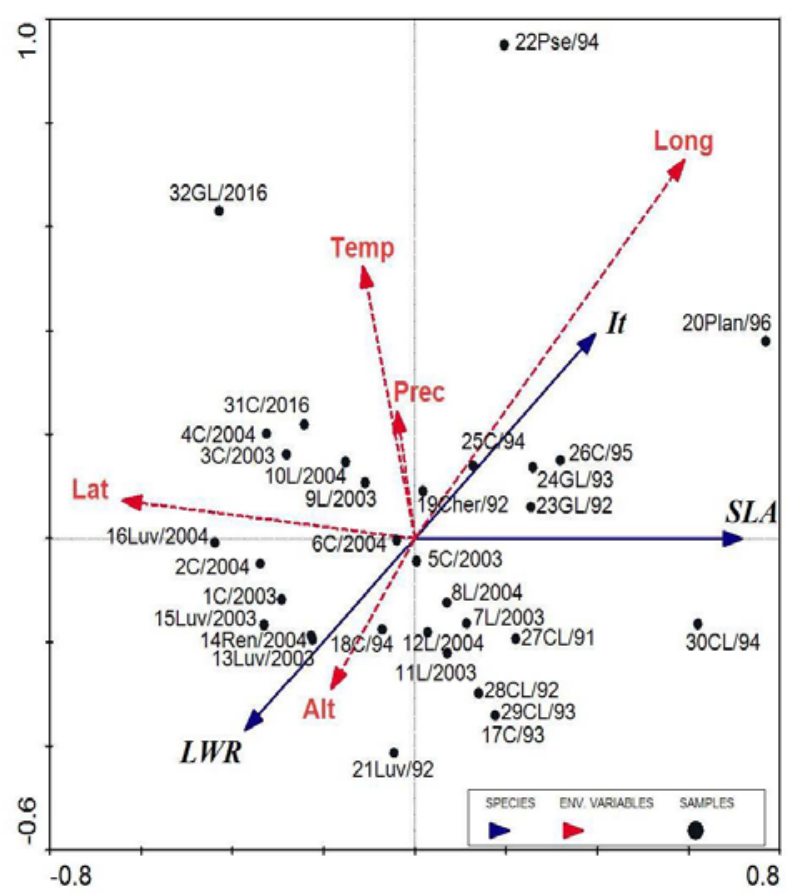

Figure 3. The RDA triples of the correlations of the three indices (species: SLA, It, and LWR) with the five environmental factors (environmental variables: Lat.; Long; Alt.; T; Prec.) and sampling locations. Statistical Results: AllEV $=1.000$, Can EV $=0.513$, F-ratio = 5.474, p-value $=0.0020$

\section{Results from ANOVA Analysis}

ANOVA analysis shows the variance of the mean, minimum and maximum values of each of the indexes (SLA, $L W R, I t$ ) by years. As a result, the differences in the values (dispersion) of each of the three indices are reliable in years for both Quercus cerris L. and Quercus frainetto Ten..

For Quercus cerris L. indices, the following variation is observed: Figure 4.

- For SLA is observed a decline in the period: 2003-2004 and 2016 compared to the period of the highest index values: 1991-1993.

- For It index is observed a decrease in the period: 1993 - 1995 compared to the high values: 1991-1992; 2003-2004 and 2016.

- For $L W R$, there is a dropped in 1995 compared to the period of the highest index values: 2003-2004. 


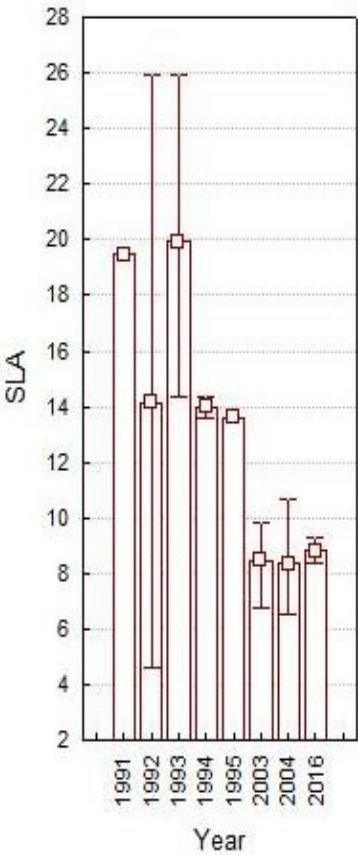

$F(7 ; 21)=3,6264 ;$
$p=0,0102$

ANOVA

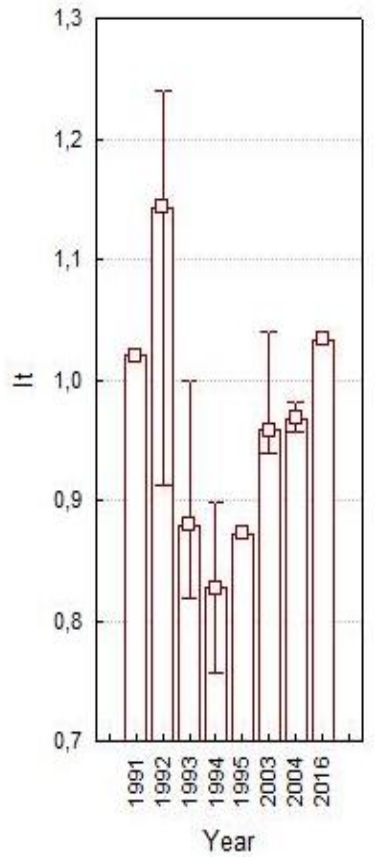

$F(7 ; 21)=5,4381$;

$\mathrm{p}=0,0011$

Quercus cerris

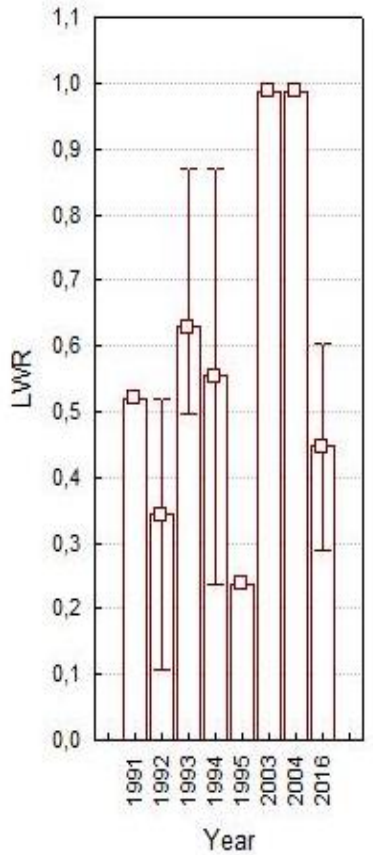

$F(7 ; 21)=14,3562$;

$p=0,000001$

Figure 4. One-factor dispersion analysis (ANOVA) per year for the Quercus cerris L

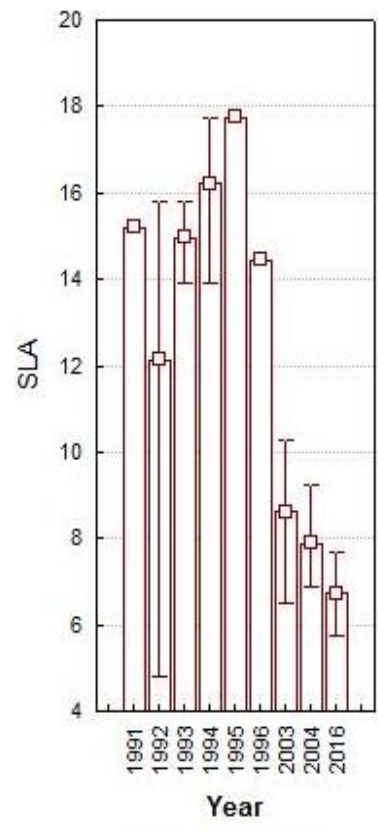

$F(8: 23)=10,7205$;

$\mathrm{p}=0,000004$

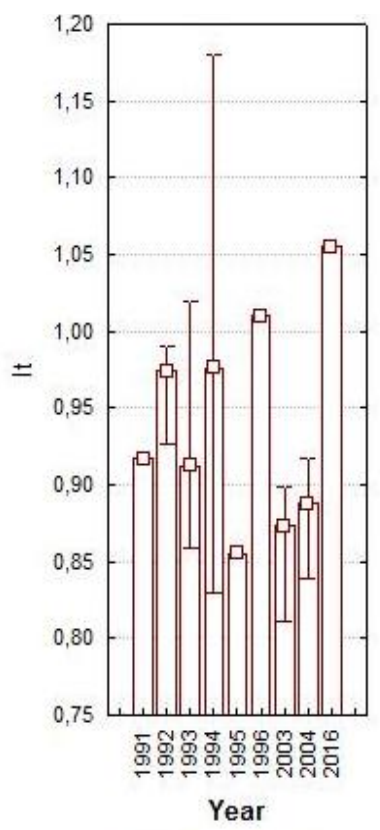

$F(8 ; 23)=2,6555$;

$\mathrm{p}=0,0318$

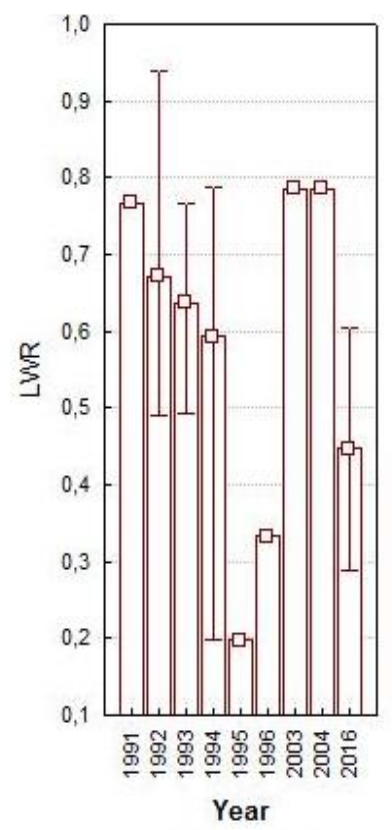

$\mathrm{F}(8 ; 23)=4,3436$; $\mathrm{p}=0,0026$

ANOVA

Quercus frainetto

믈 Mean

Figure 5. One-factor dispersion analysis (ANOVA) per year for the Quercus frainetto Ten. 
For the indexes of Quercus frainetto Ten. the following variation is observed - Figure 5.

- $\quad$ For $S L A$, there is a decline in the period: 2003-2004 and 2016 compared to the period of the highest values of the index: 1994-1995.

- $\quad$ For It there is a decline in the period: 2003-2004 compared to the high values: 1996 and 2016.

- For $L W R$ is observed a decrease in the period: 1994-1995 compared to the period of the highest values of the index: 1991, 2003-2004.

\section{Discussion}

Changes in plant functional traits have proven to be extremely useful in solving a number of issues related to the search for standardized ways to measure the impacts of global warming and climate change. The traits are an extremely blessing basis for creating dynamic and working vegetation models. This is a great potential to build a predictable set of local, regional and global links between plants and environmental factors. In this way, a wide range of natural and anthropogenic unlocking processes can be quantified, including changes in biodiversity, impacts of invasive species, changes in biogeochemical processes and plant-atmospheric interactions, Perez-Harguindeguy et al. [37].

To begin with, we will make verification between the results obtained for the surveyed indices and geographic characteristics from the RDA analysis between the Bulgarian localities and the TRY database. It proves that the results are completely identical for It index, that correlates neutral to positive with SLA index. For Bulgarian localities, SLA index correlates poorly to moderately negative with $L W R$, unlike TRY locales, where the correlation is poorly positive. LWR according to TRY data for all two species: Quercus frainetto Ten and Quercus cerris L. correlates strongly positively with It, but in Bulgarian it is the opposite - LWR correlates moderately to strongly negative with It index, but this is also found for some species at TRY data, Lyubenova et al. [32].

Links between the indices and a geographic characteristic proved to be extremely contradictory - for the Bulgarian localities and the data in TRY base. The only identical results were the following: It correlates negatively with Alt.; SLA and $L W R$ correlated negatively with Lat., but $L W R$ correlates negatively with both Alt and Long.

By discussing the results of the comparative statistical analyze, we come to a very important general conclusion about the Bulgarian and TRY data provided. It reads the following for the studied deciduous species: Quercus cerris L. and Quercus frainetto Ten - the main influence on the calculated traits (SLA, LWR and It) is the location (latitude and longitude), and to some extent the indexes affect the altitude and temperature. This is confirmed by $R D A$ analysis that proves $95 \%$ probability of the following correlations:

- It correlates negatively with Alt.

- It correlates positively with SLA.

- $\quad$ SLA correlates negatively with Lat.

- $\quad$ LWR correlates negatively with Alt., Lat. and Long.

ANOVA analysis and F-test results also showed that the differences between species, genera, years and countries in each of the 3 indexes were reliable ( $p<0.05$ ). Therefore, all statistical analyzes performed have a confidence level of $95 \%$, which is the statistical maximum for similar meta analyzes and for meta - analyzes as a whole, Debray et al. $[7,8]$.

As early as 2001, Ketterings et al. [19] suggests that forest trait wood density (WD) strongly depends on the habitat, climate and management of the forestry. This scientific work has shown that the remaining SLA, It, $L W R$ also depend mainly on the habitat and to a lesser extent on the climate. Based on the meta-analysis, a large-scale study was conducted across three continents - Europe, Asia and North America. Finally, the results were compared between Bulgaria and the habitats of the other three continents by the virtue of data in plant trait database (TRY). Due to the meta-analysis, the errors / deviations were minimized with a maximum confidence level of $95 \%$. For the future researchers in this field there is a big lack of information. We believe that this is just the beginning.

\section{Conclusions}

The meta-analysis allowed a reduction in a statistical errors and a 95\% confidence rating for such studies. Thanks to this, the following functional relationships were established with 95\% probability.

- Between the indexes and the characteristics of the localities:

It correlates negatively with Alt, and SLA correlates negatively with $L a t$. For all studied deciduous tree species and locales (TRY and Bulgarian). For its part, $L W R$ correlates negatively with Alt., Lat. and Long again in all deciduous species and locales (TRY and Bulgarian). Additional links have been proved only for the Bulgarian locales in the species Quercus cerris L. and Quercus frainetto Ten., where It and SLA correlate positively with Long.

- $\quad$ Between the SLA and LWR indices for the relevant species and habitat:

Only in Bulgarian localities was found that SLA correlates negatively with $L W R$ in both the broad-leaved species: Quercus cerris L. and Quercus frainetto Ten.

- Between the LWR, SLA and It indices for the respective species and habitat.

It correlates positively with SLA in all locales (TRY and Bulgarian) for the species: Quercus cerris L. and Quercus 
frainetto Ten. For its part, It and SLA correlate negatively with $L W R$ only in the Bulgarian localities.

Finally, the results of the Bulgarian localities were compared with those of the TRY base and the following functional links were established globally:

- It correlates negatively with Alt.

- It correlates positively with SLA.

- $\quad$ SLA correlates negatively with Lat.

- $\quad$ LWR correlates negatively with Alt., Lat. And Long.

As a conclusion, based on the conducted analyzes (ANOVA and RDA), it became clear that the influence on the calculated traits (SLA, LWR, WD and It) has the geographical coordinates or the location, and to a lesser extent some of the indices affect altitude and temperature. This was confirmed with $95 \%$ probability

In the future, based on such research, an innovative approach could be created to:

- $\quad$ Filling in the data gaps;

- Greater precision of the analyzed analyzes;

- Creating a new generation of dynamic global vegetation models, DGVMs.

\section{Acknowledgements}

We want to thank to our colleges in the Plant trait database (TRY) for their help and information about the researched traits. We are so happy that the TRY global data for traits is becoming bigger and bigger every single day! Thank you so much! We can't do this high research without your assistance.

We also want to thank to State forestry in Sevlievo, Bulgaria for their great help and assistance.

\section{REFERENCES}

[1] Atkin, O., Bloomfield, K., Reich, P., Tjoelker, M. et al. 2015. Global variability in leaf respiration among plant functional types in relation to climate and leaf traits. New Phytologist 206: pp. 614-636.

[2] Bondev, I. 1991. Vegetation of Bulgaria, map M: 1: 600000. University Publishing House "St. Kliment Ohridski", p. 183.

[3] Bondov, I. 1997. Geo-Botanic Zoning of Bulgaria. Book

[4] Bondev, I., M., Ljubenova, N., Georgiev. 1998. Overground phytomass and phytoproduction of the Quercus frainetto Ten. Tree stands in two oak communities from the northern parts of Mount Strandja. Phytologia Balkanica, vol. 4, № 3, pp. 87 $-94$

[5] Cochran, W.G. 1937. "Problems Arising in the Analysis of a Series of Similar Experiments". Journal of the Royal Statistical Society. 4: 102-118. doi:10.2307/2984123

[6] Cochran, W.G., Carroll, S.P. 1953. "A Sampling
Investigation of the Efficiency of Weighting Inversely as the Estimated Variance". Biometrics. 9: 447-459. doi:10.2307/3001436

[7] Debray, T.P., Koffijberg, H., Vergouwe, Y., Moons, K.G., Steyerberg, E.W. 2012. "Aggregating published prediction models with individual participant data: a comparison of different approaches". Statistics in Medicine. 31 (23): 26972712. doi:10.1002/sim.5412.

[8] Debray, T.P., Moons, K.G., Ahmed, I., Koffijberg, H., Riley, R.D. 2013. "A framework for developing, implementing, and evaluating clinical prediction models in an individual participant data meta-analysis". Statistics in Medicine. 32 (18): 3158-80.doi:10.1002/sim.5732

[9] Diamond, J.M. 1975. Assembly of species communities. In: Ecology and Evolution of Communities (eds Cody, M.L. \& Diamond, J.M.). Harvard University Press, Cambridge, pp. 342-444.

[10] European Environment Agency, Technical Report № $13 / 2015$.

[11] Garnier, E., Cortez, J., Bille`s, G. et al. 2004. Plant functional markers capture ecosystem properties during secondary succession. Ecology, 85, pp. 2630-2637.

[12] Georgieva, N., Lyubenova, M. 2012. Characteristics and distribution of xerothermic oak ecosystems in SCI "Zapadna Stara planina I Predbalkan” as subject of functional research. pp. $114-119$.

[13] Georgieva, N., Lyubenova, M. 2014. ECOLOGICAL STATUS OF XEROTHERMIC OAK ECOSYSTEMS SCI “ZAPADNA STARA PLANINA I PREDBALKAN”. Bulgarian Journal of Agricultural Science, 20, pp. 105-109. Agricultural Academy

[14] Grissino - Mayer, H. D. 2001. Evaluating crossdating accuracy: a manual and tutorial for the computer program COFECHA. In: Tree-ring research, VOL. 57(2), 2001, 205 $-221$.

[15] Henry, M., Besnard, A., Asante, W., Eshun, J., Adu-Bredu, S., Valentini, R., Bernoux, M., Saint-Andre, L. 2010. Wood density, phytomass variations within and among trees, and allometric equations in a tropical rainforest of Africa. Forest Ecology and Management 260, pp. 1375-1388.

[16] Hoffmann, W. A., Poorter, H. 2002. "Avoiding Bias in Calculations of Relative Growth Rate". Annals of Botany 90 (1): pp. 37-42.

[17] Jarvis, P. G. 1985. Increasing productivity and value of temperate coniferous forests by manipulating site water balance. Forest Potentials-Productivity and Value. Proceedings Weyerhaeuser Sci. Symp. Tacoma (USA), pp. 39-74.

[18] Johnson, M., Wardle, D.A. 2010. Structural equation modelling reveals plant-community drivers of carbon storage in boreal forest ecosystems. Biol. Lett. 6, pp. 116119.

[19] Katterings, Q., Coe, R., van Noordwijk, M., Ambagau, Y., Palm, C. 2001. Reducing uncertainty in the use of allometric biomass equations for predicting above-ground tree biomass in mixed secondary forests. Forest Ecology and Management, 146, pp. 199-209. 
[20] Kattge, J., Diaz, S., Lavorel, S., Prentice, I., Leadley, P., Bonisch, G., Garnier, E., Westoby, M., Reich, P., Wright, I. and 124 more authors .2011. TRY - a global database of plant functional traits. Global Change Biology 17: pp. 2905-2935.

[21] Koprinkova P., Petrova M., Patarinska T., Bliznakova M. 1998. Neural Network Modelling of Fermentation Processes. Specific Kinetic Rates Models, International Journal of Cybernetics and Systems, vol. 29, N. 3, 303-317.

[22] Kraft, N.J.B., Valencia, R., Ackerly, D.D. 2008. Functional traits and niche-based tree community assembly in an Amazonian forest. Science, 322, pp. 580-582.

[23] Lalova, J. 1994. Primary Productivity of Representative Forest Associations in North-West Bulgaria. Forest Science, Book 2, pp. 10-17.

[24] Ljubenova, M. 1993. Investigation on some functional parameters of the tree layer in association Quercus frainetto + Quercus cerris - Crataegus monogyna - Brachypodium pinnatum in the Western Balkan Mountains. Yearbook of Sofia University "St. Kliment Ohridski ", book 4, vol. 88, pp. 11 - 18 - Fifth Scientific Session, Sofia.

[25] Lyubenova, M. 1995 a. Exploration of the energy flow in the oak forests of Zemen Mountain. Vol. 3, pp. 228-236. Jubilee Scientific Session, June 7 - 9, 1995, Sofia.

[26] Lyubenova, M. 1995 b. Exploration of some functional parameters of oak forests from the Central Forebanks. Volume 3, pp. 218-227. Jubilee Scientific Session, June 7 - 9 , 1995, Sofia.

[27] Ljubenova, M., A., Akmadjov, 1995. Primary overground production of an oak ecosystem from the Zemen mountain region.

[28] Lyubenova, M., I., Bondev, B., Atanasova. 1996. Investigation of the structural and functional state of a sterling - blagun forest from the Western Serpentine forest. Forestry Thought, vol. 3, issue 8.

[29] Ljubenova, M. 1997. Investigation of some structural and functional parameters of an oak forest from the North - East Rhodopa Mountains. The society of ecologists of the Republic of Macedonia, vol. 4, № 1, pp. 3-11.

[30] Lyubenova, M. 2012. Plant functional types of tress (PFTs) according to peculiarities of periods with reduced stem growth (stress periods). Publishing house PublishSySet Eco, Sofia, 276.

[31] Lyubenova, M., V., Dimitrova, N., Georgieva, D., Dimitrov. 2014. BIOMASS OF THE XEROTHERMIC OAK ECOSYSTEM ON A SITE OF COMMUNITY IMPORTANCE, BG0001040 "ZAPADNA STARA PLANINA I PREDBALKAN”, BULGARIA. Drewno, Vol. 57, No. 192, pp. 89 - 106

[32] Lyubenova, M., Kattge, J., van Bodegom, P., Chikalanov, A., Kalcheva, H., Popova, S., Peteva, S. 2016. Preliminary Survey on TRY Forest Traits and Growth Index Relations New Challenges. Poster. European General Assembly, 17-22 April, Vienna, Austria.

[33] Mirchev, S., Lyubenova, M., Shikalanov, A., Simeonova, N. 2000. Dendrochronology (short course), Pensoft, Sofia Moscow.
[34] Nichiporovich, A. 1961. Fotosinteticheskaya deyatelynosty rasteniy v posevah. Izd. AN SSSR, Moskva.

[35] Nichiporovich, A., 1963. Fotosinteticheskaya deyatelynosty rasteniy v posevah. Izd. AN SSSR, Moskva.

[36] Nichiporovich, A. 1982. Sbornik "Fiziologiya fotosinteza", pp. 7-13.

[37] Perez - Harguindeguy, N, Diaz, S., Garnier, E and more 32 authors .2013. New handbook for standardised measurement of plant functional traits worldwide. Australian Journal of Botany, 61, pp. 167-234

[38] Poorter, H., Remkes, C. 1990. Leaf area ratio and net assimilation rate of 24 wild species differing in relative growth rate. Oecologia 83: pp. 553-559.

[39] Ramette, A., 2007. Multivariate analyses in microbial ecology. FEMS Microbiology Ecology, 62: 142-160.

[40] Strategic plan for the development of the forestry sector 2014 - 2023. Executive Agency for Forests - MAF.

[41] Ter Braak C. J. F., P. Smilauer. 2002. Canoco for Windows 4.5. Biometris, Wageningen and Ceske Budejovice, $484 \mathrm{p}$.

[42] Thibault, J. 1991. Feedforward neural networks for identification of dynamic processes, J. Chem. Eng. Comm $105,109-128$

[43] Tilman, D. 1982. Resource Competition and Community Structure. Princeton University Press, Princeton, NJ, USA, 296 pp.

[44] WALKER, E., HERNANDEZ, A. V., KATTAN, M. W. 2008. "Meta-analysis: Its strengths and limitations". Cleveland Clinic Journal of Medicine. 75 (6): 431439.doi:10.3949/ccjm.75.6.431

[45] Wilfahrt, P.A., Collins, B., White, P.S. 2014. Shifts in functional traits among tree communities across succession in eastern deciduous forests. For. Ecol. Manage., in press. http://dx.doi.org/10.1016/j.foreco.2014.01.018

[46] Wirth, C. 2005. Fire regime and tree diversity in boreal forests: implications for the carbon cycle. Forest Diversity and Function: Temperate and Boreal Systems, 176, pp. 309344.

[47] World Wildlife Fund. 2016. Report for Bulgarian forests.

[48] Wright, I.J., Reich, P.B., Westoby, M. et al. 2004. The worldwide leaf economics spectrum. Nature, 428, pp. 821827.

[49] Witkowski ETF, Lamont BB .1991. Leaf specific mass confounds leaf density and thickness. Oecologia 88: 486493

[50] Yablon, E. 2013. Functional Traits, Environmental Gradients and Community Assembly in a Temperate Forest. Washington University in St. Louis. Environmental Studies: Biology/Ecology. Senior Honors Thesis.

[51] Yordanova, P. 2016. Introduction to Statistics. Lectures.

[52] Zaehle, S., Friend, A. 2010. Carbon and nitrogen cycle dynamics in the O-CN land surface model: 1. Model description, site-scale evaluation, and sensitivity to parameter estimates. Global Biochemical Cycles, 24, doi: 10.1029/2009GB003521. 